\begin{tabular}{|c|c|c|c|c|c|c|}
\hline \multirow{4}{*}{ Impact Factor: } & ISRA (India) & $=3.117$ & SIS (USA) & $=0.912$ & ICV (Poland) & $=6.630$ \\
\hline & ISI (Dubai, UAE & $=0.829$ & РИНЦ (Russia) & $=0.156$ & PIF (India) & $=1.940$ \\
\hline & GIF (Australia) & $=0.564$ & ESJI (KZ) & $=8.716$ & IBI (India) & $=4.260$ \\
\hline & JIF & $=1.500$ & S.IIF (Moroce & $=5.667$ & OAJI (USA) & $=0.350$ \\
\hline
\end{tabular}

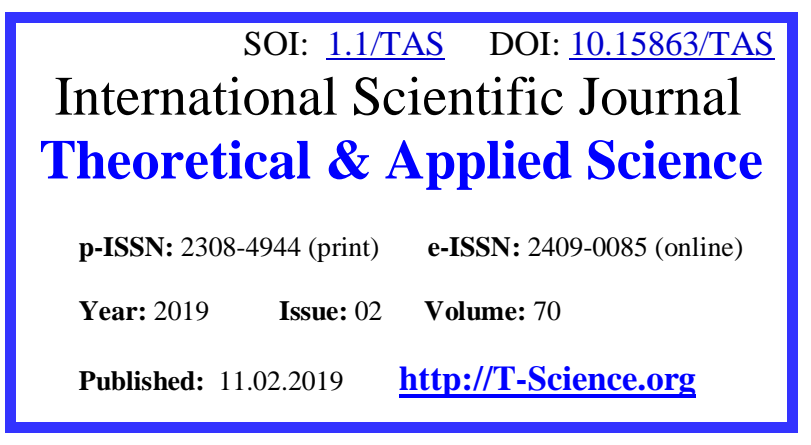

SECTION 30. Philosophy.
QR - Issue

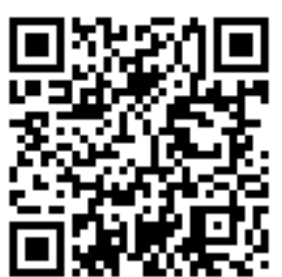

QR - Article

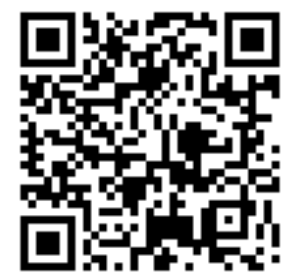

Komiljon Rakhimov

Doctor of Philosophy in Historical Science, Senior researcher at Abu Rayhan Biruni Institute of Oriental Studies of the Academy of Sciences of Uzbekistan kom_rah@mail.ru

\title{
THE DESCRIPTION OF THE SUFI MAQAMS AND HALS IN THE "SHARH AT-TA'ARRUF"
}

\begin{abstract}
The maqams and hals are the most important elements of Sufism as they represent the stages and conditions of the mystical path. Since the early periods in the history of Sufism, the different opinions about the classifications of the maqams and hals have been expressed by Sufi authors. In this regard, the description of the maqams and hals have special importance in the Persian encyclopedic work on Sufism titled the "Sharh at-Ta'arruf li-madh 'habat-tasawwuf" which was written by the 11th century Central Asian author Khoja Abu Ibrahim Isma 'il bin Muhammad bin 'Abdullah al-Mustamli al-Bukhari. In this work the author takes a special approach to the issues of the maqams and hals in Central Asian Sufi schools. The present article will examine the methods of description of maqams and hals in addition to their analyzing their characteristics in the "Sharh at-Ta "arruf".

Key words: "Sharh at-Ta 'arruf", Mustamli, Sufism, maqam and hal.

Language: English

Citation: Rakhimov, K. (2019). The description of the sufi maqams and hals in the "Sharh at-Ta'arruf". ISJ Theoretical \& Applied Science, 02 (70), 26-36.
\end{abstract}

Soi: http://s-o-i.org/1.1/TAS-02-70-6 Doi: rosef https://dx.doi.org/10.15863/TAS.2019.02.70.6

\section{Introduction}

The movement of Sufism (See on the history of appearing and the early periods of tasawwuf: Arberry, 2002; Trimingham, 2002; Knysh, 2004; Subhan, 2005; Yilmaz, 2007; Hismatulin, 2008; Nasirov, 2009; Karamatov, 1991; Turar, 1999; Komilov, 2006, 2009; Komilov and Rahimov, 2011) which began to form in various forms in many Islamic countries from the seventh and eighth centuries, began to appear as a doctrinal organization with its own theoretical principles and system of specific rules starting in the ninth century. We can say that maqam is considered the most important stage for a Sufi who is entering the mystical path and gradually passing through various maqams from the beginning to the end with an ultimate goal of reaching God in the end. In other words, the maqams and hals are the necessary components forming Sufism and the base-foundation of sayru suluk, i.e. traveling along the mystical path.

\section{Materials and Methods}

Since the early days of Sufism the different opinions were expressed concerning the variances, limits, features, types, numbers and sequences of maqams and hals. Some groups of Sufi authors did not separate the hal and maqam from each other; in other words, they saw them as the same phenomenon. On the other hand, other Sufi authors described the hal and maqam as different experiences from each other, and discussed about their distinctive types, numbers and characteristics. In particular, Abu Sulaiman Darani, one of the Sufi authors who considered the maqam and hal as a single phenomenon, discussed about the existence of three types of maqams in Sufism by noting them in the following sequence of zuhd, wara ' and rida [14, p.44.]. Shaqiq Balkhi wrote about the existence of four manzilats by noting them in the following sequence of zuhd, khawf, shawq, and muhabbat [3,p.108]. Yahya b. Muadh noted the existence of seven maqams of the sayru suluk and noted them in the sequence of tawba, zuhd, rida, khawf, shawq, muhabbat and ma'rifat. Abu Talib Makki described the existence of nine maqams in Sufism and mentioned them in the sequence of tawba, sabr, shukr, raja, khawf, zuhd, tawakkul, muhabbat and rida [14, V.1, p.200]. Abu Mansur Isfahani described forty maqams beginning with tawba and ending with himmat [7], Abu Abdurahman as-Sulami 


\begin{tabular}{|c|c|c|c|c|c|c|}
\hline \multirow{4}{*}{ 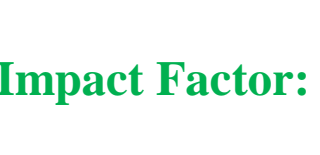 } & ISRA (India) & $=3.117$ & SIS (USA) & $=0.912$ & ICV (Poland) & $=6.630$ \\
\hline & ISI (Dubai, UAE & $=0.829$ & РИНЦ (Russia & $=0.156$ & PIF (India) & $=1.940$ \\
\hline & GIF (Australia) & $=0.564$ & ESJI (KZ) & $=8.716$ & IBI (India) & $=4.260$ \\
\hline & JIF & $=1.500$ & SJIF (Morocco & $=5.667$ & OAJI (USA) & $=0.350$ \\
\hline
\end{tabular}

depicted forty-four maqams beginning with tawba and ending with jam ' and tafriqa [24], Abdullah Ansari (1006-1089) discussed the hundred types of maqams beginning with tawba and ending with fana and baqa [1]. Ruzbehan Baqli (1128-1209) described about the existence of a thousand of maqams in total [4]. Abu Nasr Sarraj Tusi, one of the first Sufi authors who approached the maqam and hal as different experiences, mentioned that there are seven types of maqams (in the sequence of tawba, wara', zuhd, faqr, sabr,tawakkul and rida) and ten types of hals (in the sequence of muroqaba, qurb, muhabbat, khawf, raja, shawq, uns, itmi'nan, mushohada and yaqiyn) in Sufism [19]. We can say that this is the author who first tried to show the difference between hal and maqam from each other, and to give a clear definition to each of them. In particular, according to Sarraj's opinion, maqam is the stage acquired with the salik's efforts - riyazats and mujahadats, and hal takes place of the salik for it is not acquired with the result of the efforts of the salik, but it is the state given to him by Allah [19]. While in many sources tawba is mentioned as the first maqam, rida, ma'rifat, fana, baqa or ittisal are mentioned as the latest maqams in various sources. In addition, some of the concepts (like qurbah, muhabbat, khawf, raja, shawq, uns, fana and baqa) are defined as maqams in some sources while being depicted as hal in others. Besides this, the other sources mention the existence of other types of hals such as tarab, huzn, qabz, bast, haybat, ghalaba, wajd, sahw, sukr, ghaybat, huzur $[9$, p. 152,$266 ; 10 ; 27 ; 23 ; 18 ; 21]$. Taking into consideration the above mentioned information, we can conclude that, throughout the history of Sufism a clear distinction between hals and maqams in Sufism was not made, and generally accepted conception concerning the types, numbers, features and sequence of each of them was not formed. In other words, every Sufi school, sect or tariqat and also every prominent Sufi author created their own specific system of maqams and hals.

The "Sharh at-Ta'arrufli madh'habat-tasawwuf" ("The Comments on the Instruction of the Sufi Doctrine") [16] written by the Central Asian scholar Khoja Abu Ibrahim Ismail b. Muhammad b. Abdullah al-Mustamli al-Bukhari at the beginning of the eleventh century. It is not only the first source on Sufism written in Persian, but is also an important encyclopedic work which includes the knowledge on Sufism produced up to that period in addition to containing the detailed descriptions of the hals and maqams in Sufism. It should be noted that the author of the "Sharh at-Ta'arruf" tried to create a system of maqam and hals differing from the descriptions of previous Sufi authors that was distinct in terms of its approach concerning the types, numbers and characteristics of the maqams and the hals.

Meanwhile, the efforts in researching the description of hals and maqams in Sufism such as muhabbat [20], dhikr [5], sabr [22], faqr [15] by a number of Iranian scholars in recent years, along with other Sufi themes covered in the "Sharh atTa'arruf", could be mentioned among the first steps toward better understanding this phenomenon. However, firstly, these researches discuss briefly and generally the "Sharh at-Ta'arruf" while disregarding the detailed examination of the maqam or hal described in the "Sharh at-Ta'arruf;"on the other hands, they are just satisfied with providing brief descriptions of certain maqam or hal from the general Sufi sources. Secondly, it is difficult to say that the relevant themes were sufficiently and deeply studied in the parts of these articles concerning the clarification of the specific maqam and hal in the "Sharh at-Ta'arruf". Thirdly, these publications do not approach comprehensively a question of clarification of the hals and maqams of Sufism in the "Sharh at-Ta'arruf".

By the way, it is worth mentioning that the "Sharh at-Ta'arruf", unlike many sources of Sufism written before that time, was developed as an encyclopedic source covering many aspects of Sufism including the definition, theory, history and terminology of Sufism and hagiography of Sufis while the main body of the text is dedicated to the theory of Sufism. The majority of the work regarding the theory of Sufism is directly dedicated to the description and definition of the hals and maqams of Sufism.

Mustamli considered hal and maqam as separate experiences differing from each other. In this regard, it is necessary to mention the baseless conclusion of Maryam Sha'bonzoda, an Iranian researcher of Sufism, who suggests that: "Mustamli talked about thirty maqams in the "Sharh at-Ta'arruf" while not separating them into hals and maqams" [21, p.130]. Particularly, the Iranian researcher, first of all, does not show clearly what those "thirty maqams"that Mustamli speaks about consist of; and, secondly, for some reason, she adds Mustamli, who views the maqam and hal as separate experiences while making clear descriptions of them, into a group of Sufi authors who consider maqam and halas the same phenomenon not separating them from each other. Although Mustamli indeed looked at the maqams and hals mentioned in his work not separately from each other, but in mixed way in addition to not showing clearly if some parts of them would be included to the number of maqams and hals, it cannot be concluded that he considered the concepts of maqams and hals as the same experience. Because, first of all, in the "Sharh at-Ta'arruf" the clear description of maqams and hals is provided, and secondly, it was informed that the majority of the hals and maqams listed in the work is a maqam or a hal in the direct or indirect manner.

In particular, when Mustamli looks at the hal and maqam as separate experiences depending each 


\begin{tabular}{|c|c|c|c|c|c|c|}
\hline \multirow{4}{*}{ 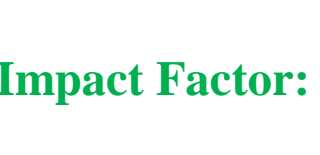 } & ISRA (India) & $=3.117$ & SIS (USA) & $=0.912$ & ICV (Poland) & $=6.630$ \\
\hline & ISI (Dubai, UAE & $=0.829$ & РИНЦ (Russia & $=0.156$ & PIF (India) & $=1.940$ \\
\hline & GIF (Australia) & $=0.564$ & ESJI (KZ) & $=8.716$ & IBI (India) & $=4.260$ \\
\hline & JIF & $=1.500$ & SJIF (Morocco & $=5.667$ & OAJI (USA) & $=0.350$ \\
\hline
\end{tabular}

other, he attempts in the first place to show their place in Sufism in the system called the Sufi levels. According to him, for the person the first stage that must be achieved in mystical path is 'ilm (knowledge), the second stage is wajd, the third stage is hal and the fourth stage is maqam [16, Vol.1, p.195]. In other words, the person must learn the Sufi knowledge of the mystical path, then he must have the ability of entering the wajd, after that he should achieve the stages of maqam and hal. Mustamli describes the relatedness of the Sufi levels to one another which can be traced in the following sequence:"Hals prove maqams, wajds prove hals, knowledge proves wajd, speaking proves knowledge. It cannot be spoken based on knowledge until it is obtained, knowledge cannot appear until wajd takes place, wajd cannot take place until hal is right, hal does not appear until one reaches the maqam of the rightness. In addition, whose maqam is right, his halis hijab in maqam, whose hal is pure, wajd makes him ghayib from hal, whose wajd is right, he does not need to speak based on knowledge." [16, Vol.1, p.195].

Unlike some authors like Abu Mansur Isfahani (1367 (1988)) who considers the maqam subject to hal, Mustamli marks the hal as a subject to maqam. According to him, the Sufi adept does not achieve the maqam until the hal occurs in him. However, the Sufi adept may not achieve the maqam in all of the situations when hal happens to him. There is a possibility of such cases when the Sufi adept does not achieve the maqam although the hal happens to him [16, Vol.1, p.197]. According to Mustamli, in the situations when maqam occurs after experiencing hal, hal is not the causing reason for maqam to come into effect:"... while hal is correct, maqam comes because of the correctness of hal, but hal is not the reason for achieving maqam" [16, Vol.1, p.196]. Mustamli regards the hal as an experience which should occur not only before the maqam, but which could occur within the framework of the maqam: "Each maqam has the beginning and end; there are a variety of hals between this beginning and end" [16, Vol.3, p.1146].

Mustamli has a view on the nature of the maqam and hal different from other authors. In particular, he said, the first three of Sufi levels knowledge, wajd and hal, are the qualities of the Sufi adept, and the maqam which is the fourth level is not considered as a quality of the adept [16, Vol.1, p.195]. Because, in his opinion, halis the clothes of the adept, but maqam is Allah's robe [16, Vol.1, p.196]. In other words, unlike most of the authors, including Sarraj Tusi [19, p.36] who regards maqam as the thing acquired as a result of salik's efforts, hal is not related to the adept's efforts and it is something that is given by Allah. Mustamli regards the hal as the experience which is achieved as a result of the deeds of the adept, namely, foretold by
Allah, but the maqam is an experience whic his given by Allah: "The knowledge of Sufism is knowledge of the hals, and the hals are the harvest of the deeds. Those who follow correctly achieve the hals. Deeds are the execution of the rules of Shari'ah, hals are that is being chosen of the secret". Mustamli says concerning of the hal being subject to the deeds, i.e. the efforts of the adept, the following: "The hals in the interior of those whose deeds are proper in the exterior. If one finds or sees something in his interior, and supposes it to be a miracle (karamat) from Allah presented to him, he should follow this call. If his deeds are right in front of God and he fulfills the rules of shari'ah as they are made compulsive, the thing he finds in his interior is the miracle of God" [16, Vol.3, p.1119].

The main body of text consisting of the twentyfour chapters (except for the forty-fifth chapter that is about the wajd and the fiftieth chapter is about the tajalliy and istitar) located from the twenty-seventh chapter to the fifty second chapter of the "Sharh atTa"arruf", which consists of the total of sixty-eight chapters, is dedicated to the description of the Sufi hals and maqams. While Mustamli does identify the specifics of the maqams and hals in his work, he gives the detailed information and comments on twenty-seven hals and maqams in the separate chapters (tawba, zuhd, sabr, faqr, tawazi', khawf, taqwa, ikhlas, shukr, tawakkul, rida, yaqiyn, dhikr, uns, qurbah, ittisol, muhabbat, tajrid and tafrid, ghalaba, sukr, ghaybat and shuhud, jam 'and tafriqa, fana and baqa), in addition to describing the other hals and maqams including four hals and maqams in the chapters on the other themes (shawq, sahw, raja, inbisat); that's thirty-one maqams and hals in all. Meanwhile, it should be noted that in various Sufi sources, as well as in various research works, the parities of the maqams and hals, such as sukr and sahw, ghaybat and shuhud, jam ' and tafriqa, tajrid and tafrid, fana and baqa are described differently, and some authors regard each of these parities as an integral part of maqam or hal while others mention that there are two distinct maqams or hals subject to each other in these pairs. Each of these parities is studied as a distinct maqam or hal which is related to one another in the "Sharh at-Ta'arruf". According to this, we have told that the total number of the hals mentioned by Mustamli is not twenty-seven, but thirty-one.

As mentioned above, Mustamli described some of the hals and maqams directly as maqam and hal, and specified if it is maqam or hal while describing the others indirectly in his work. However, it is not identified whether the remaining four experiences can be classified as maqams or hals in a direct or indirect way in the "Sharh at-Ta 'arruf". However, it can be defined if the author considered them belonging to the maqams or hals based on the characteristics described by Mustamlias the specific 


\begin{tabular}{|c|c|c|c|c|c|c|}
\hline \multirow{4}{*}{ Impact Factor: } & ISRA (India) & $=3.117$ & SIS (USA) & $=0.912$ & ICV (Poland) & $=6.630$ \\
\hline & ISI (Dubai, UAE & $=0.829$ & РИНЦ (Russia & $=0.156$ & PIF (India) & $=1.940$ \\
\hline & GIF (Australia) & $=0.564$ & ESJI (KZ) & $=8.716$ & IBI (India) & $=4.260$ \\
\hline & JIF & $=1.500$ & SJIF (Morocco & $=5.667$ & OAJI (USA) & $=0.350$ \\
\hline
\end{tabular}

marks to them. In particular, Mustamli depicted the eight experiences belonging to maqams directly, among which are tawba, zuhd, tawakkul, dhikr, uns, qurbah, fana and baqa, while identifying the four experiences rida, ittisol, tajrid and tafrid as belonging to maqams indirectly. In addition, he describes as the nine experiences -sabr, khawf, raja, shukr, muhabbat, shawq, ghalaba, sukr, and sahw belonging to hals directly while the six experience such as -yaqiyn, ghaybat, shuhud, jam', tafriqa and inbisat belonging to hals indirectly. In particular, Mustamli says the following about the belonging of these experiences to maqams:

Tawba: "Tawba is the return from jafa and it is the first maqam among maqams" [16, Vol.1, p.227].

Zuhd: "The first maqam among the maqams of murids is zuhd" [16, Vol.3, p.1219].

Tawakkul: "...people do not need to be engaged in the maqam of tawakkul for God to make other activities adequate for them" [16, Vol.3, p.1302].

Dhikr: "The first of the maqams is the maqam of dhikr and it is the maqam of the disciples and ghayibs" [16, Vol.3, p.1333].

Uns: "After the body returns to this world, who looks at it, he has found ... hope from the uns of the maqam he achieved." [16, Vol.3, p.1351].

Qurbah: "If they want to give him izz and wealth, he refuses to accept it feeling shy. In the end, he will be in qurbah of the maqam" [16, Vol.3, p.1363].

Fana: "... who ever reaches fana of the maqam and his fana is in God, as we mentioned above, he always fulfills the divine tasks" [16, Vol.4, p.1635].

Baqa: "... fana is the maqam of being faniy from the people (khalq), and baqa is the maqam of being baqiy with God" [16, Vol.4, p.1576].

Rida: "Rabi'a was in such a maqam that she would know them both as rawa if Allah punished or did not punish her. Because Rabi'a was pleased with God's actions to her" [16, Vol.3, p.1314].

Ittisal: "Sahl b.'Abdullah said: "they made those move who claim:"We have reached this hal,"sending distress. After they moved, they certainly lost God. If they had been silent when the distress came, they would join God" [16, Vol.3, p.1377].

Tajrid: "... whoever has not been perfected in the tajrid of maqam, and there is still something left in him, he is called nafsiy" [16, Vol.4, p.1426].

Tafrid: "... to be fard from own forms happens in two kinds of forms. First of all, he wants to see people, and he is appalled when he does not see people. The second, he is appalled when he sees people and wants not to see people. This maqam is superior" [16, Vol.4, p.1434].

Mustamli mentions about considering the following experiences in the category of hals:
Khawf, raja, sabr, shukr, muhabbat, and shawq: "The hals are of interior quality and khawf or raja, are considered to be among those. Fear for persistence and hope for meeting, patience for trouble and gratitude for favor; muhabbat and shawq are all considered among the interior hals" [16, Vol.4, p.1810].

Ghalaba: "...ghalaba is the hal that happens to the adept ; at the same time the adept cannot understand the reasons and he cannot keep adab as well" [16, Vol.4, p.1469].

Sukr: "... According to the opinion of those who belong to this group, sukr is the hal happening to the adept ; adept loses the ability to distinguish between good and evil, he is not able to distinguish between benefit and damage" [16, Vol.4, p.1488].

Sahw: "Sheikh also talked about the hal of sahw which happens after sukr while reminding the hal of sukr in this book" [16,Vol.4, p.1493].

Yaqiyn: "If the adept's yaqiyn is not right, hishalin batin is not healthy" [16, Vol.3, p.1184].

Ghaybat, shuhud: "...he is in such a state in the hal of ghaybat and hazrat (shuhud) that he is not aware of those ghaybat and hazrat themselves" [16, Vol.4, p.1512].

Jam':"... jam'is considered as jam 'only when it becomes the adept's hal." [16, Vol.4, p.1525].

Tafriqa: "Tafriqa which is being talked about is the tafriqa which happens before jam" "[16, Vol.4, p.1534].

Inbisat: "... the more muhabbat becomes , the love of Allah becomes more for the adept, the more the love of Allah gets for the adept, the more the amount of uns gets, the bigger uns is, the bigger inbisatis ... inbisat does not happen till muhabbat and uns do not happen" [16, Vol.3, p.1353].

Though in the "Sharh at-Ta'arruf" nothing was told about directly if some experiences such as faqr, tawazi ', taqwa and ikhlas are classified as maqams or hals, according to the description of these experiences by Mustamli we can understand that the author considered faqr and taqwa as maqams, tawazi ${ }^{\text {‘ }}$ and ikhlas ashals. In particular, about these events Mustamli said the following:

Faqr: "You know that faqris a great basis for the foundation of the sect for the people who belong to this group." [16, Vol.3, p.1239].

Khawf: "... for the special (khas) people food for travel is taqwaand animal to ride is tawakkul" [16, Vol.3, p.1095].

Tawazi':"The quality of tawazi' consists of the adept's inclining to experiencing the distress he encounters" [16, Vol.3, p.1259].

Ikhlas: "... if there's no shirk in the heart of the adept when he confirms with the heart, in his tongue when he confesses with tongue and in his deeds when he fulfills with his body, he will become fully a khalis of the God. Then the members of his body are 


\begin{tabular}{|c|c|c|c|c|c|c|}
\hline \multirow{4}{*}{ Impact Factor: } & ISRA (India) & $=3.117$ & SIS (USA) & $=0.912$ & ICV (Poland) & $=6.630$ \\
\hline & ISI (Dubai, UAE & $=0.829$ & РИНЦ (Russia & $=0.156$ & PIF (India) & $=1.940$ \\
\hline & GIF (Australia) & $=0.564$ & ESJI (KZ) & $=8.716$ & IBI (India) & $=4.260$ \\
\hline & JIF & $=1.500$ & SJIF (Morocco & $=5.667$ & OAJI (USA) & $=0.350$ \\
\hline
\end{tabular}

characterized with the quality of the ikhlas" [16, Vol.3, p.1030-1031].

It should be noted that in his work, Mustamli showed the maqams and hals not in a separate way, but in a mixed way while providing the definitions of hals associated with the maqams to some degree in the chapters after certain sections on these maqams. For example, the chapter on the hal of sabr which is associated with the maqam of zuhd comes after the chapter on this maqam, or the chapter on the hal of tawazi " which is associated with the maqam of faqr comes after the chapter on this maqam.

At first glance at the "Sharhat-Ta'arruf"it looks as if the fixed order of the sequence of the maqams is not given. In particular, Mustamli noted each of the maqams of tawba, zuhd, and dhikr as the first maqam in different places, and he did not identify which is the last maqam among the maqams. For example, in one place he says: "Tawba is the return from jafa (badness), and it is the first maqam among the maqams" [16, Vol.1, p.227], and in the chapter of the workon zuhd: "Among the maqams of murids the first maqam is zuhd", [16, Vol.3, p.1219] and in the chapter on dhikr he described dhikr as the first maqam saying: "The first of maqam is dhikr and this maqam is the maqam of talibs and ghayibs" [16, Vol.3, p.1333]. However, if we approach the question deeper, it becomes clear that Mustamli had a certain view on both of the sequences of maqams of Sufism, namely the first and last maqam. In particular, Mustamli considered each one of the maqams of tawba, zuhd, and dhikr not as the first maqam of the general sayru suluk, but the first maqam of different stages in sayru suluk - returning from jafa, murid and talib. It should be noted for Mustamli, the adept enters the way of murid after returning from jafa (badness) and fulfilling tawba, then proceeds to the way of talib [16, Vol.4, p.1702]. Based on this, we can understand that Mustamli considered the maqam of tawba as the first maqam of Sufism in general, and mentioned the maqams of zuhd and dhikr as the first maqams in the stages of murid and talib. Mustamli's view on the sequence of the maqams of Sufism almost corresponds to the sequences of the chapters on maqams in the "Sharh at-Ta'arruf," where the maqams of Sufism begin with the maqam of tawba and end with the maqam of baqa. Only here the maqam of ittisal which actually comes before the maqam of fanais described in the previous chapters on the maqams of tajrid and tafrid that come after the maqam of qurbah.

Based on the above mentioned information, we can talk about that the following numbers, types and sequences of maqams and hals of Sufism which are described in the"Sharh at-Ta'arruf":

The fourteen maqams: tawba, zuhd, faqr, taqwa, tawakkul, rida, dhikr, uns, qurbah, ittisal, tajrid, tafrid, fana, baqa.
The seventeen hals: sabr, tawazi', khawf, raja, ikhlas,shukr, yaqiyn, muhabbat, shawq, ghalaba, sukr, sahw, ghaybat, shuhud, jam ', tafriqa, inbisat.

The classification of the maqams and hals in Sufism characterized by Mustamli correspond to the types of the maqams and hals characterized by the majority of the other Sufi authors. The only difference is that the maqam called wara' in other Sufi sources is named taqwa in the "Sharh atTa 'arruf" and the hal called bast by the other authors is named inbisat by Mustamli. Besides this, in some cases Mustamli gave the Persian translation along with the main Arabic names of the hals and maqams. In particular, in some places of the "Sharh atTa'arruf'the word dervishi is used instead of the word faqr, dusti is used instead of the word muhabbat, umid is used instead of the word raja, and gustahi is used instead of the word inbisat are used.

As we closely examine the text we will see that Mustamli considered the maqams and hals as separate experiences while showing the border between them, and secondly, although he considered each of the maqams and hals within the limit of the specified system, in particular, he showed the exact sequence of the maqams which begins with tawba and ends with baqa. Moreover, in the "Sharh atTa arruf" maqams and hals were foremost regarded as the experiences which are special in Sufism in the overall context, and only after this it was paid attention if they were from maqams or hals. It is worth mentioning that the majority of the Sufi authors talked about the relationship between the hal and maqam, and expressed their opinion concerning hal in salik turning into maqam after becoming permanent. [18, p.307]

Although this point was not explained directly in the"Sharh at-Ta'arruf", such approach is observed in Mustamli's some descriptions on the hals and maqams. In other words, Mustamli considers some events as hal in some places, and as maqam in other places. In particular, he described as a hal the experiences such as uns, fana, baqa which he had described as a maqam in some places. The examples:

Uns: "So, it is essential to be aware that the uns is a great thing." [16,Vol.3, p.1349].

Fana: "When the hal of fana happens to the adept, you can see the truthfulness of this hal in which he is mahfuz on the thing ordered to him by Haqq." [16, Vol.4, p.1572].

Baqa: "The condition of Mustafa that we mentioned can serve as an example of baqa." [16, Vol.4, p.1576].

As a result of this it occurs that though Mustamli did not speak directly about turning of the hal in salik into a maqam when it becomes permanent, he mentioned indirectly that some of the maqams are in the form of hal at the beginning. In particular, in many places of the "Sharh at-Ta'arruf" 


\begin{tabular}{|c|c|c|c|c|c|c|}
\hline \multirow{4}{*}{ Impact Factor: } & ISRA (India) & $=3.117$ & SIS (USA) & $=0.912$ & ICV (Poland) & $=6.630$ \\
\hline & ISI (Dubai, UAE & $=0.829$ & РИНЦ (Russia & $=0.156$ & PIF (India) & $=1.940$ \\
\hline & GIF (Australia) & $=0.564$ & ESJI (KZ) & $=8.716$ & IBI (India) & $=4.260$ \\
\hline & JIF & $=1.500$ & SJIF (Morocco & $=5.667$ & OAJI (USA) & $=0.350$ \\
\hline
\end{tabular}

it is talked about the Sufi's hal which is faniy from himself.

Similarly, Mustamli noted as a maqam such events as sabr, khawf, muhabbat, raja, ghaybat and shuhud which he described as a hal himself in some places. The examples:

Sabr: "Sabr is a great maqam ..." [16, Vol.3, p.1227]. "...without the help of the Most High servant will not reach the maqam of sabr." [16, Vol.3, p.1230].

Khawf, raja, ghaybat, shuhud: "... if he is in the maqam of khawf, he makes $w a$ ' $d$ nafiy and makes wa'idthabit. Similarly, when he is in the maqam of raja, he makes wa'id nafiy and makes wa' $d$ thabit, when he is in the maqam of ghaybat, he makes Haqq nafiy and khalq thabit, in the maqam of mushahadat he makes khalq nafiy and Haqq thabit." [16, Vol.3, p.1154].

However, Mustamli doesn't think that all the hals turns into maqam or all the maqams were hals at the beginning. In addition, there is more probability that the word "maqam" which is used in relation to the experiences described as "hal"in some points of the "Sharh at-Ta'arruf"is used not in the meaning expressing the maqam of Sufism which means one of the stages of sayru suluk, but in the meaning of the stage obtained within the circle of a certain hal. Accordingly, our above conclusions regarding the border, number, types and sequence of the maqams and hals defined by Mustamli can be considered as the most correct, clear and firm conclusions concerning this matter.

In addition to the above-mentioned maqams and hals, some other experiences are also covered which can be called as a maqam or halat certain points in the "Sharh at-Ta'arruf". These include the experiences such mushahadat (contemplation), mukashafat , ta'zim (worship, praise), respect, haybat (awe), and hayrat (surprise). Though Mustamli noted each of these conditions belonging to a hal or maqam in different places, he did not consider them firmly as maqams or hals.

As Mustamli describes the maqams and hals of Sufism he explains first the lexical meaning of each of them, then the meaning used in normal life of the people or Shari'ah, and after that he provides the Sufi meaning of them, and clarifies if the Sufi meaning is used in certain cases. Thus we have determined the number, types, border and sequence of the maqams and hals in the "Sharh at-Ta'arruf", and now below we present the brief composition of the descriptions to each of these maqams and hals described by Mustamli.

\section{Maqams:}

Tawba [repentance, a retreat or a return] is refraining of the servant from praying when he considers his worship lacking of any worth (i.e. not considering his worship worthy), and paying attention only to Allah's goodness. At the same time, whatever deeds a servant does, he considers them not worthy of Allah, and he makes an excuse for his obedience as a disobeying rebel. Tawba of another Sufi group consists of avoiding khalq (people, world) back to the haq, while considering that it is possible to get harm or benefit from people.

Zuhd [austerity] is abstaining from the life of this world to attain nearness to Allah tabarak wata'ala considering as in the sense that this world and all the things in it have no significance. Zuhd has several levels, the first level of it is abstaining from wealth, the second level is to keep the heart free, the last level is refraining from anything which nafs can take pleasure in this world. Some zahids understand that zuhd is abandoning not only this world and all the things belonged to it, but that world and all the things that belonged to it and being together only with Allah.

Faqr [poverty, penury] is behaving of the servant as poor, needy and feeble before Allah, not trying to possess the things of the world. A real faqr is the servant's need for Allah. After all, wealth is the quality of Allah, penury is the quality of the servant, a servant is indigent, even if he owns the whole world. Faqr is one of the bases of Sufism.

Taqwa [avoiding, piety] is the servant's avoiding all the things that can be a barrier on the road of reaching Allah. The basis of taqwa consists of two things: fearing and avoiding. The servant's taqwa from the Lord is in two forms. That is servant is afraid of punishment or firaq (separation) from Allah. The signs of the servant's fear for the punishment of Allah is that he complies with the orders and prohibits (amrs and nahiys) and saves the right sand ranges (hadd) of the conversation with the Haqq. If the servant's taqwa from Haqq is in the view of the fear for firaq, the servant avoids what is below Haqq and isn't satisfied with what is below Haqq in order not to become separated from Haqq.

Tawakkul [perfect trust in Allah and reliance on Him alone] is to rely on Haqq alone in his life and to entrust every thing related to his fate to the judgment of Allah, contenting with one's fate determined by Him and knowing all the events and the good and bad things in his daily life and in the world from God.

Rida [contentment, agreement] is to accept and to content with any taqdir and irada (willing) predestined for him by Allah in the eternal past, and in addition to this, it is to believe that Allahu ta'ala definitely wishes good and advantageous things for the servant, to be satisfied and contented with Allah's judgment for him.

Dhikr [remembering] is to remember Allah. It is called true dhikr (remembering) when one should forget the other thing during dhikr except the one being remembered. Dhikr can be performed either with tongue, or in secret. The true dhikr does not 


\begin{tabular}{|c|c|c|c|c|c|c|}
\hline \multirow{4}{*}{ Impact Factor: } & ISRA (India) & $=3.117$ & SIS (USA) & $=0.912$ & ICV (Poland) & $=6.630$ \\
\hline & ISI (Dubai, UAE & $=0.829$ & РИНЦ (Russia & $=0.156$ & PIF (India) & $=1.940$ \\
\hline & GIF (Australia) & $=0.564$ & ESJI (KZ) & $=8.716$ & IBI (India) & $=4.260$ \\
\hline & JIF & $=1.500$ & SJIF (Morocco & $=5.667$ & OAJI (USA) & $=0.350$ \\
\hline
\end{tabular}

happen till the servant forgets the other things except Haqq.

Uns [getting /falling into the habit] is to get the habit of" being together with"Allah, and to stay away (to be ghayib) from seeing all the other things except Him.

Qurbah [closeness to Allah] is the strict observance of the amrs (commandments) and nahiys (prohibitions) of Allah, not thinking, imagining and paying attention to all other things except Allah and the situation of closeness to Allah by means of mukashafat and mushahadat. Qurbah takes place in sufi'sfeeling himself close to Allah, indirectly feeling the presence of Allah, understanding Allah's eyes on him.

Ittisal [merger, joining] is the servant's giving upall other things except Allah in secret, not seeing, hearing and remembering all other things except Allah in the meaning of glorifying Allah. Ittisal is the condition occurring after qurbah or the result of qurbah.

Tajrid [separation, revealing] is the servant's separating himself from all other things except Allah to stay alone with Allah. Tajridis divided into two types: external and internal tajrid, and external tajridis to separate himself from this world and all the things in this world, internal tajridis not to demand anything in this and that world in exchange for separating himself from this world and all the things in the world.

Tafrid [staying alone, getting alone] is the condition occurring after tajrid, and the servant's separating himself from all creatures created by Allah, getting alone and staying with only Allah. Servant will not be alone with Allah until he is separated from people.

Fana [disappearing, getting lost] is the servant's not seeing his existence, essence, characteristics and actions, or considering himself not to have existence, essence, characteristics and actions, and all belongs to Allah; being faniy from himself, getting lost, losing himself, losing his own "I" in the meaning of seeing no existence except Allah.

Baqa [subsistence, duration] is being baqiy of the servant in the features which are peculiar to Allah after being fana from all the features which are peculiar to him. Baqa is real only if it occurs after fana.

\section{Hals:}

Sabr [patience] is bearing of the servant with any trouble sent by Allah without expecting salvation from anyone except Allah. A higher level of sabr is that while being in sabr the servant does not see his sabr (patience), i.e. he does not consider himself to do sabr. While the servant is sabir (patient) not seeing the distress he encountered, that is, not to think of it to be a trouble, and he is sabir in sabr not seeing sabr, that is not to think himself doing sabr.
Tawazi ${ }^{6}$ [humility] is the servant's inclining to experience the distress he encounters while obeying the rules (or supremacy) of Allah and not objecting to His commands and approving of what He does.

Khawf [fear] is not the fear of the torment by Allah, but fear of Allah's glory. Because the torment is something done on the body, so the fear for his body is not considered to be the fear of Haqq. The fear of Haqq is the condition of iyman (faith), and iyman does not achieve baqa but for khawf.

Raja [hope] is the servant's hope for Allah's kindness. The sign of khawf (fear) is to escape, and the sign of raja (hope) is to search. Kindness brings hope, haybat brings fear. The essence of hope is being busy with worship, the essence of the fear is leaving ma'siyat (evil). The stronger the hope is, the more muti' servant is, the stronger the fear is, the farther from evil servant is.

Ikhlas [sincerity] is not to bring people's dissimulation and vanity of self for making the servant's deeds clean from bad things, his aim for his deeds should be not hope of sawab (or thawabreward), but the consent of Haqq, whatever he has done, he should not see his doings, that is, he should not think that he has done them himself.

Shukr [thankfulness] is to do shukr (to thank) for gratitude of Allah, seeing this gratitude, but not his ta 'at during the servant's ta 'at for Allah. After servant does shukr for Allah, Allah increases tawfiq which He gives him. As a result, another ta 'at will be carried out by him, and servant also does shukr for it. If servant does shukr tirelessly, Haqq gives him tawfiq tirelessly. In fact, the servant is not able to fulfill Allah's sake. So, servant must fulfill the following two things so that shukr appears: to make iqrar that shukr is wajib and to confess to making a lack of fulfilling Allah's sake. Then Allah accepts his lack as fullness.

Yaqiyn [firm confident] is to take action to benefit all servants of Allah while firmly believing; the slave who believes it to see.

Muhabbat [love] is, first of all, the worship which the slave must fulfill for Haqq, secondly, to have love for Allah without any hope for anything from minnat (grace) that Haqq does. The servant's love for Allah is the result of the love of Allah for the servant, and the love of Allah for a servant consists of His willing of goodness, servant's love for Allah consists of his ta'at to Allah. Allah's love is the quality which has existed since azal (eternity with respect to the past, eternity without beginning)and any goodness shown to the servant is the result of the eternal love. Allah's love is true love, the love of the slave is figurative love.

Shawq [enthusiasm] is the condition from the triumph of love, the stronger the love is, the stronger the enthusiasm is. Love looks like fire and enthusiasm looks like the tongue of that fire. The stronger the fire gets, the longer its tongue stretches. 


\begin{tabular}{|c|c|c|c|c|c|c|}
\hline \multirow{4}{*}{ Impact Factor: } & ISRA (India) & $=3.117$ & SIS (USA) & $=0.912$ & ICV (Poland) & $=6.630$ \\
\hline & ISI (Dubai, UAE & $=0.829$ & РИНЦ (Russia & $=0.156$ & PIF (India) & $=1.940$ \\
\hline & GIF (Australia) & $=0.564$ & ESJI (KZ) & $=8.716$ & IBI (India) & $=4.260$ \\
\hline & JIF & $=1.500$ & SJIF (Morocco & $=5.667$ & OAJI (USA) & $=0.350$ \\
\hline
\end{tabular}

The longer its tongue stretches, the more it burns. Enthusiasm is also similar to it. Fire burns wood, and shawq burns desire, thoughts and body. Anyone who claims to love something, then they are in its shawq, a sign of love for them will be on him. So if they put any of the things that belong to the two worlds in front of him, he does not have a look at it because of shawq of it.

Ghalaba [to overcome, to gain victory; to be overpowered with spiritual ecstasy] is the servant's losing himself in the view of disappearing of the imagine about ni'mats from the servant's mind as the result of the fear coming out while watching Haqq's jalal and 'adamat (grandeur), the horror of qiyamat, the torment of the Fire, and in the result of the emotion of shukr (grace) coming out while watching the troubles or karams of Haqq (because any kind of distress or pain is nothing right before the firaq of Haqq and any ni'mat is nothing before the Lord'swisal). At the same time, the servant does the actions which he does not want to. When this situation occurs, servant cannot comply with adabs which must be complied in shari'ah. But at that moment he is considered as ma'zur (excusable) because of ghalaba of this thing.

Sukr [intoxication, loss of discernment] is loss of discernment of the ability to differentiate things and events, including the good and bad, profit and loss, hardship and ease, the pain and the pleasure from each other as the result of the ghalaba of Haqq, that is, the victory of the mind of Allah. Ghalaba and sukr which occur to Sufis only occurs for the sake of Haqq. That is, they give themselves up to achieve the consent of Haqq that they do not notice this even if they lose both of the worlds. Sukr is more preferable than sahw (soberness). Because sukr is not to see the goodness of the two worlds, but to see the evil of the two worlds on oneself.

Sahw [vigilance] is that the slave chooses hardships instead of pleasure, anguish instead of enjoyment after coming out of the condition of sukr in order to find thawab and to get the reward in that world. In this situation the servant is grateful when he enjoys, he is patient when he anguishes.

Ghaybat [absence, concealment] is the servant's disappearance from his egoistic gratifications, that is, forgetting and giving up the pleasure of his egoistic gratifications, that is, he does not pay attention to them; the servant's disappearance from great importance to this transient world and transient things in this world, after the servant has seen the eternity and baqiy Allah. In ghaybat the servant feels as if he was not in this world though he is in this world, and he feels as if he was in that world though he is not in that world. Thus, his faniy hazir vanishes, and his baqiy ghayib is present (that is, his transient existence is gone, his baqiy and constant concealment appears in front of his eyes).
Shuhud [appearance] is the servant's look at the minnat of Mawla who prohibited close relations with the things and being busy with Haqq, after his disappearance from the gratifications of his nafs, that is, getting far away from the things. Shuhud is that servant looks at not himself, but Allah. At the same time, a servant accepts all things according to not his nafsaniy (egoistic) desire and shahwat, but his servantness and obedience to Allah.

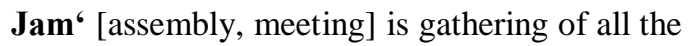
efforts of the servant and becoming a single effort, being carried out for only one thing - to reach Allah. Being jam' of servant's efforts, that is focused on one thing is the first stage of jam'. At the same time, all the efforts of the servant becomes a single one. That is, while the efforts of ordinary people are considered as mutafarraq, that is, focused on several things for they want to achieve different things with their efforts; for Sufis' efforts are focused on one thing - to reach Allah, their efforts are considered as mujtama', that is, focused on one thing. If the person whose efforts are mutafarraq devotes himself to ikhlas instead of riya (showing off), tawhid instead of shirk, humility instead of pride, all his efforts are focused on reaching Allah.

Tafriqa [separation] isthe fulfillment of servant's efforts for reaching a variety of things and digressing from Allahin the end. Allah can destroy one whose efforts are mutafarraq, that is, focused on a few things, in one of the valleys of destruction. The valley of nafs, the valley of the shaytan, the valley of the given to this world and the valley of the given to the khalq are considered as the four valleys making the efforts mutafarraq. These four valleys are the valleys of destruction.

Inbisat [rejoicing and daring] is servant's keeping himself free and daring to ask anything for himself at Allah's presence after being the witness for the lutf, karam and sahavat of Allah. Inbisatis the condition which occurs after uns or in the maqam of uns. After all, the more muhabbat gets, the more the love of Allah for the servant gets, the more the love of Allah for the servant gets, the more the amount of uns gets, the bigger uns is, the bigger inbisatis. Inbisat does not happen till muhabbat and uns do not happen initially. There is hajat (need) for inbisatwhen uns is naqis (imperfect). However, after uns gets perfect, there is no need for inbisat.

We have arrived at the following conclusions of this research which is focused on the description of the maqams and hals of Sufism in the"Sharh atTa'arruf" by Mustamli Bukhari:

1. Since the early periods of Sufism there were different opinions regarding the difference, limit, characteristics, types, numbers and sequence of the maqams and hals in Sufism, a group of people who viewed hal and maqam as the same phenomenon described the maqams from three to thousand types , and the second group of people, who considered hal 


\begin{tabular}{|c|c|c|c|c|c|c|}
\hline \multirow{4}{*}{ Impact Factor: } & ISRA (India) & $=3.117$ & SIS (USA) & $=0.912$ & ICV (Poland) & $=6.630$ \\
\hline & ISI (Dubai, UAE & $=0.829$ & РИНЦ (Russia & $=0.156$ & PIF (India) & $=1.940$ \\
\hline & GIF (Australia) & $=0.564$ & ESJI (KZ) & $=8.716$ & IBI (India) & $=4.260$ \\
\hline & JIF & $=1.500$ & SJIF (Morocco & $=5.667$ & OAJI (USA) & $=0.350$ \\
\hline
\end{tabular}

and maqam as different experiences, spoke about the numbers, various types and features of them. In other words, not only Sufi schools and tariqats (sects), but sometimes every great Sufi author createdhis specific system of maqams and hals.

2. In the work of the "Sharh at-Ta'arruf"the detailed description of the maqams and halsof Sufism is provided, besides that the author attempted to create a system which differs in terms of the numbers, types and characteristics described in the works of the previous authors with its specific approach to this issue, but this aspect of the work is still poorly researched. In recent years, although a number of Iranian researchers have carried out some efforts to research the description of some of Sufi maqams and hals in the work of "Sharh at-Ta'arruf", in these publications the related topics have not been studied closely enough and there is no integrated approach to the issue of the description of the maqams and hals of tasawwuf in the work of "Sharh at-Ta'arruf".

3. Unlike several authors, Mustamli considered maqam and hal as different experiences. In particular, Mustamli considered hal and maqam to be separate experiences depending on each other, and firstly, he attempted to show their place in Sufism within the system of mystical stages. . According to him, the first degree which must be achieved in the Sufi path is ilm (knowledge), the second stage is wajd, the third stage is hal and the fourth stage is maqam.

4. Unlike some of the authors who considered maqam to be dependent from hal, Mustamli marked hal as an experiences to be dependent on maqam. According to him, until hal occurs to the servant, he never reaches maqam. However, one not always reaches maqam in all situations in which the hal occurs. This means that such hals, which do not reach maqam, often occurs.

5. Unlike most authors who considered maqam to be reached as the results of the servant's own efforts, and hal not to be related to the efforts of the servant and to be given by Allah, Mustamli considered hal to be reached as the result of the actions, namely, to be made karamah by Allah as the result of the servant's actions, and maqamas an event to be given by Allah.

6. Mustamli provided thorough information and reviews on twenty-seven (tawba, zuhd, sabr,faqr, tawazi‘,khawf, taqwa, ikhlas, shukr, tawakkul, rida, yaqiyn, dhikr, uns, qurbah, ittisal, muhabbat, tajrid and tafrid, ghalaba,sukr, ghaybat and shuhud, jam" and tafriqa, fana and baqa) in the special chapters, other four (shawq, sahw, raja, and inbisat) maqams and hals in the chapters on other maqams and hals, as well as in the chapters on other themes - thirty-one maqams and hals in total in his work.

7. In his work Mustamli described some of the maqams and hals as maqam and hal directly while describing some of them as maqam and hal indirectly. In particular, Mustamli commented on the eight experiences - tawba, zuhd, tawakkul, dhikr, uns, qurbah, fanaand baqa belonging to maqams directly, the four experiences - rida, ittisal, tajrid and tafrid belonging to maqams indirectly, as well as nine experiences -sabr,khawf, raja, shukr, muhabbat, shawq, ghalaba, sukr, and sahw belonging tohals directly, and the six experiences yaqiyn, ghaybat, shuhud, jam', tafriqa and inbisat belonging to the hals indirectly.

8. Though it was not said directly in the "Sharh at-Ta'arruf"about whether some experiences such as faqr, tawazi', taqwa and ikhlas belong to the maqam or hals, we can understand according to the author's definition that that Mustamli regarded faqr and taqwa as maqams, tawazi‘ and ikhlas as hals.

9. In his work Mustamli described maqams and hals not in a special way and in one order, but in a mixed way, after the chapters on certain maqams he associated them with the chapters on the definition of the hals concerning the same maqams.

10. In the "Sharh at-Ta'arruf"the following types, numbers and sequences of the maqams and hals in Sufism are described:

The fourteen maqams: tawba, zuhd,faqr, taqwa, tawakkul, rida, dhikr, uns, qurbah, ittisal tajrid, tafrid, fana and baqa.

The seventeen hals: sabr, tawazi', khawf, raja, ikhlas ,shukr, yaqiyn, muhabbat, shawq, ghalaba, sukr, sahw, ghaybat, shuhud,jam', tafriqa, inbisat.

11. The types or names of the Sufi maqams and hals defined by Mustamli match the types or names of the maqams and hals described by the majority of other Sufi authors. The only thing is that the maqam named wara' in other Sufi sources was named taqwa, the hal named bast by other authors was called inbisat by Mustamli in the"Sharh at-Ta'arruf".

12. Though like other Sufi authors Mustamli did not speak about directly that the hal in salik turns into maqam when it becomes permanent, buthe reminded indirectly that some of the maqams could be in the form of halat the beginning. In particular, he reminded the experinces such as uns, fana and baqa,which he described as maqams and as hals in some places.

13. Mustamli noted the events such as khawf, muhabbat, raja, ghaybat and shuhud, which he described as hals and as maqams in some places. However, the word "maqam" used for the experiences described as"hal" inthe"Sharh atTa'arruf" was more likely used not in the meaning of Sufi maqam which expresses one of the stages of sayru suluk, but in the meaning of the stage reached within the certain hal.

14. Though Mustamli noted each of the situations such as mushahadat, mukashafat, ta'zim (praise),hurmat, haybat (fear) and hayrat as the experiences similar to the maqam and hal in various 


\begin{tabular}{|c|c|c|c|c|c|c|}
\hline \multirow{4}{*}{ Impact Factor: } & ISRA (India) & $=3.117$ & SIS (USA) & $=0.912$ & ICV (Poland) & $=6.630$ \\
\hline & ISI (Dubai, UAI & $=0.829$ & РИНЦ (Russia & $=0.156$ & PIF (India) & $=1.940$ \\
\hline & GIF (Australia) & $=0.564$ & ESJI (KZ) & $=8.716$ & IBI (India) & $=4.260$ \\
\hline & JIF & $=1.500$ & SJIF (Morocco & $=5.667$ & OAJI (USA) & $=0.350$ \\
\hline
\end{tabular}

points, he did not consider them belonging to maqams or hals firmly.

\section{References:}

1. Ansari, K. A. (1993). Hundred areas [in Persian], [Collection of Farsi brochures]. First edition. Prepared for publication by Sarvar Mawlai. Teheran: "Tus".

2. Arberry, A. J. (2002). Mistiki islama (Mysticism of Islam) [in Russian]. (pp.47-101). Moscow: Sphera.

3. Balkhi, S. A. A. (1987). Risalat adab al-ibadat. [in Persian] Trans. from Arabic by Nasrullah Purjavadi. "Ma 'arif" magazine, No.1, 108.

4. Baqli, S., Ruzbihan, A. M. (1973). Mashrab alarwah. Prepared for publication by Latif Mehrojkhoja. Istanbul: "Kulliyat al-adab".

5. Dastjerdi, T. X., \& Kazimi, M. (2011). The improving effect of the dhikr on walking towards Allah. "Adabiyat-i irfani" (Irfani literature) semiannual journal of scientific research at Az-Zahra University [in Persian]. Teheran. No. 4, 39-42, 46, 48.

6. Hismatulin, A. A. (2008). Sufism. SaintPetersburg: "Azbuka-klassika". (pp. 5051). "Peterburgskoe Vostokovedenie" (St. Petersburg Oriental Studies).

7. Isfahani, A. M. (1988). Nahj al-khass. [in Persian] Trans. from Arabic by Nasrullah Purjavadi. Journal of Islamic Studies, No. 1-2, 105-132.

8. Karamatov, H. S. (1991). Asketicheskie $i$ sufiyskie techeniya $v$ Khorasane.(The ascetic and sufi movements in Khorasan) (On "Kashf al-mahjub" Hujviri) // In the collection of "Iz istorii sufizma: istochniki $i$ social'naya praktika". (From the history of Sufism: sources and social practice). In acad. ASof R.Uz. M. M. Hayrullaeva (Eds.). (pp.27-48). Tashkent: "Fan".

9. Kamilov, N. (2009). Tasawwuf. Islam. Enciklopedicheskiy slovar. (Islam. Encyclopedic dictionary). [in Russian] pp. 152, 266.

10. Knysh, A. D. (2004). Musulmanskiy misticizm. Kratkaya istoriya (Muslim mysticism. Short history) M. G.Romanov. (pp.10-127). Saint Petersburg: "DILYA".

11. Komilov, N. (2006). Tasawwuf. (pp.3-15). Tashkent: at TashSOI.

12. Komilov, N. (2009). Tasawwuf. (pp.9-21). Toshkent: "Uzbekistan".
13. Komilov, N., \& Rahimov K. (2011). Khojagon tariqati va Buxoroda irfoniy-falsafiy ilmlar rivoji (IX-XV asrlar).(Tariqat of Khojagon and the development of irfani (moral) and philosophical sciences in Bukhara (IX-XV centuries) (pp.6-17). Tashkent: "Akademiya".

14. Makki, A. T. (1892). Qut al-qulub fi muomalat al-mahbub wa wasfu tariq al-murid ila maqom at-tasawwuf. Volume 1, 2. (p.44). Cairo: "Daru Sadir".

15. Muazzini, A. M., \& Alizada, A. A. (2011). The concept of faqr in the poetry of Haqaniy // magazine "Zaban and adabi Farsi" (Persian Language and Literature) at Independent Islamic University [in Persian]. (p.78). Teheran. 8.

16. Mustamli, A-B., Abu, I. I. M. (1984-1987). Sharh at-Ta'arruf li-madh'hab at-tasawwuf [in Persian]). 5 volumes. Prepared for publication by Muhammad Ravshan. Volumes 1, 2, 3, 4, 5. (pp. 2332). Teheran: "Asatir". After this it is given shortly as "Sharh at-Ta 'arruf" in the text and as "Sharh at-Ta'arruf li-madh'hab attasawwuf" in the reference.

17. Nasirov, I. R. (2009). Osnovaniya islamskogo misticizma (genezis i evolyuciya) (The bases of Islamic mysticism (genesis and evolution). (pp. 56-83). Moscow: "Yaziki slavyanskih kul'tur" (Languages of Slavonic cultures).

18. Sajjadi, S. (1991). Dictionary of irfani terms and phrases [in Persian]. The second edition. The seventh publication. (pp. 307-310, 735739). Teheran: Tahuriy.

19. Sarraj, A. N. A. A. (2001). Al-Luma'fi-t-ta'rikh at-tasawwuf al-islamiy. Prepared for publication by Mustafa al- Handaviy. (p.36). Beirut: "Dar al-kutub al-'ilmiya".

20. Sayyadi, M. M., \& Ahmad R. (2009). spring. Which one is better: ishq or muhabbat? Threemonth journal of the Department of Literature and Arts at the University of Kerman named after Shahid Bohunar [in Persian]. Iran, Kerman, Issue 25, 277-278

21. Sha'bonzoda, M. (2012-2013). The notional evolution of the moral (irfaniy) notion of "hal" till Hegira Qamariy VIII (Christian calendar XIV) century. "Gawhari go 'yo" (Speaking diamond) Journal of the researches of Irfani 


\begin{tabular}{|c|c|c|c|c|c|c|}
\hline \multirow{4}{*}{ Impact Factor: } & ISRA (India) & $=3.117$ & SIS (USA) & $=0.912$ & ICV (Poland) & $=6.630$ \\
\hline & ISI (Dubai, UAE & $=0.829$ & РИНЦ (Russia & $=0.156$ & PIF (India) & $=1.940$ \\
\hline & GIF (Australia) & $=0.564$ & ESJI (KZ) & $=\mathbf{5 . 0 1 5}$ & IBI (India) & $=4.260$ \\
\hline & JIF & $=1.500$ & SJIF (Morocco & $=5.667$ & OAJI (USA) & $=0.350$ \\
\hline
\end{tabular}

Literature [in Persian], Teheran issue 23, 125148.

22. Shujari, M. (2008). Ilohiy omonat eronlik so'fiylar va Ibn Arabiy nigohida.(Divine savings (amanat) in the eyes of Iranian Sufis and Ibn Arabi). Journal of the Department of Literature and Arts at the University of Tabriz. [in Persian], Iran, Tabriz, No. 204, 87.

23. Subhan, J. A. (2005). Sufizm. Yego svyatie $i$ svyatini (Sufism. The saints and sacred places of it) (pp.12-22). SaintPetersburg: "DILYA".

24. Sulamî, A. A. (1990). Darajot al-muamalat. Prepared for publication by Ahmad Taheri
Iraqi. [Collection of Sulamî's works, Volume 1]. (pp.477-495). Teheran: "Nashri donishgohiy".

25. Trimingham, S. J. (2002). Sufiyskie ordeni $v$ islame (Sufi orders in Islam) A. A. Staviskoy, edited by and preface of O. F. Akimushkina. (pp.25-93). Moscow: "Sofiya", "Gelios".

26. Turar, U. (1999). Tasavvuf tarixi. (History of tasawwuf). (pp.49-61) Tashkent: "Istiqlol".

27. Yilmaz, H. K. (2007). Tasawwuf and tariqats. A. Urmanova. (pp.60-101). Moscow: "SAD". 